\author{
Masako Matsuda • Masato Tsukahara • Osamu Kondoh \\ Hiroshi Mito
}

\title{
Familial isolated noncompaction of ventricular myocardium
}

\begin{abstract}
We report a family in which two male sibs were affected with isolated noncompaction of ventricular myocardium (INVM). The familial occurrence of INVM suggests a genetic basis. We review the literature of familial and nonfamilial cases and discuss the inheritance pattern of INVM.
\end{abstract}

Key words Familial occurrence $\cdot$ Ventricular non-compaction

\section{Introduction}

The developing myocardium gradually condenses, and the large spaces within the trabecular meshwork flatten or disappear. Isolated noncompaction of ventricular myocardium (INVM) (sometimes called spongy myocardium or persisting myocardial sinusoids) is reported to represent an arrest in endomyocardial morphogenesis (Engberding and Bender 1984; Jenni et al. 1986), and is characterized by numerous, excessively prominent trabeculations and deep intertrabecular recesses. INVM is defined as not being associated with other abnormalities and is extremely rare (Goebel et al. 1985). Ritter et al. (1997) reported the prevalence of INVM was $0.05 \%$ of adult patients examined by echocardiography.

Some cases of INVM reported to date are sporadic, and others are familial. Genetic analysis by Bleyl et al. (1997a,b) have represented six patients of INVM from one family, and they suggested the genetic linkage to the Xq28 region.

M. Matsuda $(\square) \cdot$ M. Tsukahara

School of Allied Health Sciences, Yamaguchi University, Ube,

Yamaguchi 755, Japan

Tel. +81-836-22-2832; Fax +81-836-22-2130

e-mail: tosmy-ygc@umin.ac.jp

O. Kondoh $\cdot$ H. Mito

Department of Pediatrics, Saiseikai Yamaguchi Hospital,

Yamaguchi, Japan
We present two sibs with INVM, review previous reports on INVM, and discuss the pattern of inheritance of this disease.

\section{Case Report}

A 12-year-old boy was noted to be of less than normal development (height, $143 \mathrm{~cm}$; weight, $38 \mathrm{~kg}$ ), but he did not have any cardiac symptoms. He was the child of a healthy and nonconsanguineous, 25-year-old, primigravid mother and a 28 -year-old father. Pregnancy and delivery were unremarkable. There was no history of medication, irradiation, or viral illness during the pregnancy. None of his relatives died of sudden cardiac death, congestive heart failure, or stroke. He was first noted to have electrocardiographic abnormalities in a school health examination and was referred for further evaluation.

Physical examination on admission revealed normal cardiac sounds and no murmurs. There was no facial dysmorphism. Pulse rate was $60 / \mathrm{min}$ and regular. Electrocardiogram showed normal sinus rhythm, left-axis deviation, and T-wave inversion in the left precordial leads. During exercise test, the bigeminy type of ventricular premature beats were observed. Chest X-ray was normal. Two-dimensional echocardiographic examination disclosed numerous prominent trabeculations with the deep intertrabecular recesses in the apical area (Fig. 1A), which were less prominent and less numerous near the level of the mitral valve. The abnormal trabeculation was not observed in the right ventricle. No other echocardiographic abnormalities were observed. Pressures of left and right heart catheterization were normal. In the left ventriculogram, end-diastolic volume index was $118 \mathrm{ml} / \mathrm{m}^{2}$ and ejection fraction was $58 \%$. Left and right coronary angiograms were normal. Left ventricular contour was irregular in the apical area. Left ventricular myocardial biopsy from the apical area revealed thickened endocardium with elastic tissue. By avoiding hard exertion, he has been free of symptoms. He has been taking an anticoagu- 

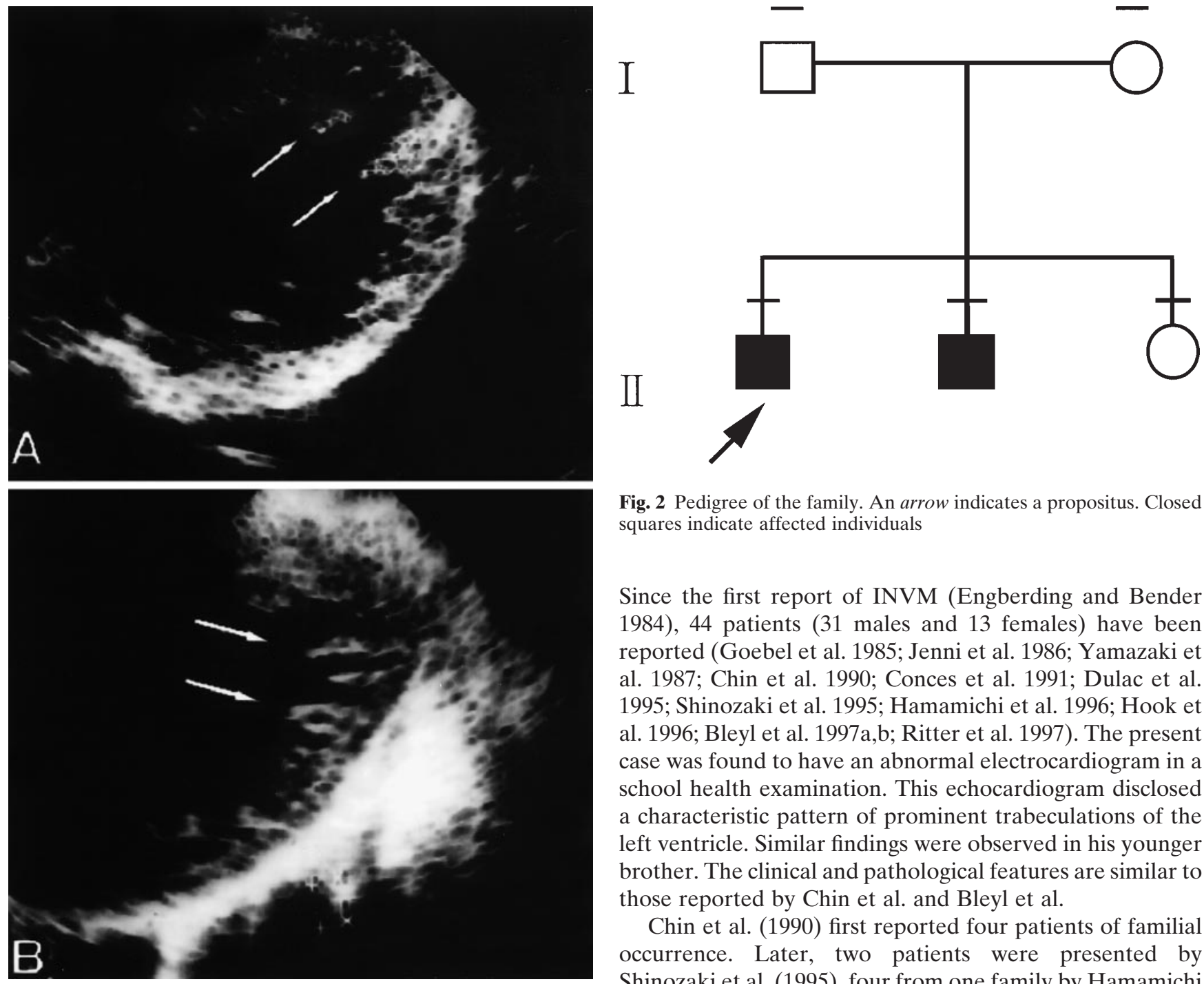

Fig. 2 Pedigree of the family. An arrow indicates a propositus. Closed squares indicate affected individuals

Since the first report of INVM (Engberding and Bender 1984), 44 patients (31 males and 13 females) have been reported (Goebel et al. 1985; Jenni et al. 1986; Yamazaki et al. 1987; Chin et al. 1990; Conces et al. 1991; Dulac et al. 1995; Shinozaki et al. 1995; Hamamichi et al. 1996; Hook et al. 1996; Bleyl et al. 1997a,b; Ritter et al. 1997). The present case was found to have an abnormal electrocardiogram in a school health examination. This echocardiogram disclosed a characteristic pattern of prominent trabeculations of the left ventricle. Similar findings were observed in his younger brother. The clinical and pathological features are similar to those reported by Chin et al. and Bleyl et al.

Chin et al. (1990) first reported four patients of familial occurrence. Later, two patients were presented by Shinozaki et al. (1995), four from one family by Hamamichi

Fig. 1 Two-dimensional echocardiogram of the patient (A) and his younger brother $(\mathbf{B})$. Long-axis view in end-diastole shows numerous prominent left ventricular trabeculations (arrows) with increased depth of intertrabecular recesses

lant (dipyridamole) for the prevention of endocardial clot.

Electrocardiographic and echocardiographic studies were performed for the parents and siblings of the patient (Fig. 2). Electrocardiograms were normal. Exercise tests were not performed. On echocardiography, the boy's younger brother had significant trabeculation in the left ventricle, but not in the right ventricle (Fig. 1B); this was not observed in their parents or younger sister. None of the family members had facial dysmorphism.

\section{Discussion}

The occurrence of INVM seems to be more frequent than has been previously considered since the diagnosis has been facilitated by the use of two-dimensional echocardiography. et al. (1996), two from one family by Ritter et al. (1997), and six from one family by Bleyl et al. (1997a). Within these seven families, including our case, all but one finding occurred in sibs (Table 1). Bleyl et al. (1997a) reported three male sibships from a fourth generation family. They demonstrated the INVM locus was located in the Xq28 region by linkage analysis. This condition is suggested to be an Xlinked recessive inheritance. Previously, the Xq28-located tafazzin (G4.5) gene (TAZ) has been mapped in Barth syndrome (Bolhuis et al. 1991; Bione et al. 1996). Thus, INVM has been considered to be allelic with the Barth syndrome (MIM*302060). In male sibs with apparently normal parents, the occurrence of INVM can be explained on the basis of X-linked recessive inheritance.

All except two families reported by Hamamichi et al. (1996) and Ritter et al. (1997) support this interpretation. Two pairs of the siblings reported by Hamamichi et al. (1996) were cousins, and their fathers were brothers. This apparent nonpenetrance in the transmitting fathers in these kindred may be explained by suppressive effect of a gene, which suggests of autosomal dominant inheritance with reduced penetrance. A pair reported by Ritter et al. (1997) consisted of a father and a daughter. In these two families, 
Table 1 Familial occurrence of noncompaction of ventricular myocardium

\begin{tabular}{|c|c|c|c|}
\hline & Sex & $\begin{array}{l}\text { Age } \\
\text { (years) }\end{array}$ & $\begin{array}{l}\text { Facial } \\
\text { dysmorphism }\end{array}$ \\
\hline \multirow[t]{2}{*}{ Chin et al. (1990) } & M & 2.3 & + \\
\hline & M & 9 & + \\
\hline \multirow[t]{2}{*}{ Chin et al. (1990) } & M & 14.5 & - \\
\hline & M & 13 & - \\
\hline \multirow[t]{2}{*}{ Shinozaki et al. (1995) } & M & 17 & N.D. \\
\hline & M & 13 & N.D. \\
\hline \multirow[t]{2}{*}{ Hamamichi et al. (1996) ${ }^{a}$} & $\mathrm{~F}$ & 18 & N.D. \\
\hline & M & 17 & N.D. \\
\hline \multirow[t]{2}{*}{ Hamamichi et al. (1996) ${ }^{\mathrm{a}}$} & $\mathrm{F}$ & 18 & N.D. \\
\hline & $\mathrm{F}$ & 16 & N.D. \\
\hline \multirow[t]{2}{*}{ Ritter et al. (1997) } & M & 50 & - \\
\hline & $\mathrm{F}$ & 23 & - \\
\hline \multirow[t]{2}{*}{ Bleyl et al. (1997 a) ${ }^{b}$} & M & 0 & - \\
\hline & M & 0 & - \\
\hline \multirow[t]{2}{*}{ Bleyl et al. (1997 a) ${ }^{b}$} & M & $3.5 \mathrm{M}$ & - \\
\hline & $\mathrm{M}$ & $5 \mathrm{~W}$ & - \\
\hline \multirow[t]{2}{*}{ Bleyl et al. (1997 a) ${ }^{c}$} & M & $7 \mathrm{M}$ & - \\
\hline & M & $6 \mathrm{~W}$ & - \\
\hline \multirow[t]{2}{*}{ Present cases } & M & 12 & - \\
\hline & M & 10 & - \\
\hline
\end{tabular}

N.D., not described; M, male; F, female

${ }^{\mathrm{a}}$ The fathers are brothers

${ }^{\mathrm{b}}$ Maternal half-cousins

${ }^{\mathrm{c}}$ Nephews of sibs above

autosomal dominant inheritance with reduced penetrance or multifactorial inheritance might be more suitable explanations.

In addition to these 3 female patients with familial occurrence, 10 female patients without familial traits who had clinical manifestations similar to those of 33 male patients also exclude the possibility of X-linked recessive inheritance. Further molecular studies of individuals with INVM may provide more information to determine the inheritance pattern of INVM and to conclude whether this condition constitutes one distinct entity or is heterogeneous.

Acknowledgments This work was supported in part by a grant-in-aid for Scientific Research (C) 09670810 from the Ministry of Education, Science, Sports and Culture of Japan (M.T.).

\section{References}

Bleyl SB, Mumford BR, Brown-Harrison MC, Pagotto LT, Carey JC, Pysher TJ, Ward K, Chin TK (1997a) Xq28-linked noncompaction of the left ventricular myocardium: prenatal diagnosis and pathologic analysis of affected individuals. Am J Med Genet 72: 257-265

Bleyl SB, Mumford BR, Thompson V, Carey JC, Pysher TJ, Chin TK, Ward K (1997b) Neonatal, lethal noncompaction of the left ventricular myocardium is allelic with Barth syndrome. Am J Hum Genet 61: 868-872

Bolhuis PA, Hensels GW, Hulsebos TJM, Baas F, Barth PG (1991) Mapping of the locus for X-linked cardioskeletal myopathy with neutropenia and abnormal mitochondria (Barth syndrome) to Xq28. Am J Hum Genet 48: 481-485

Bione S, D'Adamo P, Maestrini E, Gedeon AK, Bolhuis PA, Taniolo D (1996) A novel X-linked gene, G4.5. (sic) is responsible for Barth syndrome. Nat Genet 12: 385-389

Chin TK, Perloff JK, Williams RG, Jue K, Mohrmann R (1990) Isolated noncompaction of left ventricular myocardium. A study of eight cases. Circulation 82: 507-513

Conces DJ, Ryan T, Tarner RD (1991) Noncompaction of ventricular myocardium: CT appearance. AJR Am J Roentgenol 156: $717-$ 718

Dulac Y, Heitz F, Baunin C, Roux D (1995) Persistence of spongy myocardium: apropos of a case. Arch Mal Coeur Vaiss 88: 761764

Engberding R, Bender F (1984) Echokardiographischer Nachweis persistierender myokardialer sinusoide. Z Kardiol 73: 786-788

Goebel N, Jenni R, Gruntzig A (1985) Persistierende myokardiale Sinusoide. Fortschr Roentgenstr 142: 692-693

Hamamichi Y, Kamiya T, Singaki Y, Ono Y, Echigo S, Tanada I, Takamiya M, Iida K, Yamatani C, Naito H (1996) Familial occurrence with isolated noncompaction of the myocardium (abstract). Acta Cardiol Paediatr Jpn 12: 220

Hook S, Ratliff NB, Rosenkranz E, Sterba R (1996) Isolated noncompaction of the ventricular myocardium. Pediatr Cardiol 17: $43-45$

Jenni R, Goebel N, Tartini R, Schneider J, Arbenz U, Oswald O (1986) Persisting myocardial sinusoids of both ventricles as an isolated anomaly: echocardiographic, angiographic, and pathologic anatomical findings. Cardiovasc Interventional Radiol 9: 127-131

Ritter M, Oechslin E, Sutsch G, Attenhofer C, Schneider J, Jenni R (1997) Isolated noncompaction of the myocardium in adults. Mayo Clin Proc 72: 26-31

Shinozaki K, Hashimoto I, Hamamichi Y, Tsubata S, Miyazaki A, Ichita M, Okada T, Sakazume S (1995) Impaired cardiac function with prominent apical trabeculation in siblings (abstract). Acta Cardiol Paediatr Jpn 11: 390

Yamasaki S, Yon C, Honda M, Honda K (1987) A report of unusual case with abnormal muscular bands in left ventricle. Shinzo 19: 13211325 